\title{
Food intolerance in rheumatoid arthritis. II. Clinical and histological aspects
}

\author{
M A F J van de Laar, M Aalbers, F G Bruins, A C H M van Dinther-Janssen, \\ J $\mathrm{K}$ van der Korst, C J L M Meijer
}

\begin{abstract}
Six patients with rheumatoid factor positive rheumatoid arthritis who had shown a marked symptomatic improvement during four weeks of hypoallergic, artificial diet were studied in greater detail. Placebo controlled rechallenges showed intolerance for specific foodstuffs in four patients. In three of these patients biopsies of both the synovial membrane and of the proximal small intestine were carried out before and during allergen free feeding. In two patients, both with raised serum IgE concentrations and specific IgE antibodies to certain foods, a marked reduction of mast cells in the synovial membrane and proximal small intestine was demonstrated. Although the number of food intolerant patients with RA remains limited and markers of allergic activity are scanty, our observations suggest an underlying immunoallergological mechanism.
\end{abstract}

Department of

Rheumatology,

Jan van Breemen

Instituut and Academisch

Medisch Centrum,

University of

Amsterdam, Amsterdam,

The Netherlands

M A F J van de Laar

J $\mathbf{K}$ van der Korst

Department of

Allergology,

Central Laboratory of

the Netherlands Red

Cross Blood Transfusion

Service of Amsterdam,

The Netherlands

$M$ Aalbers

Department of

Occupational

Dermatology,

Academisch Ziekenhuis

Vrije Universiteit,

Amsterdam,

The Netherlands

F G Bruins

Department of

Pathology,

Academisch Ziekenhuis

Vrije Universiteit,

Amsterdam,

The Netherlands

A C H M van Dinther-

Janssen

C J L M Meijer

Correspondence to:

Dr M A F J van de Laar,

Department of

Rheumatology,

Jan van Breemen

Institute,

Dr Jan van Breemenstraat 2,

1056 AB Amsterdam,

The Netherlands.

Accepted for publication

16 July 1991
For many years patients and doctors have been intrigued by the notion that certain foods or food components might influence rheumatoid arthritis (RA). In the past decade the influence of food intolerance, particularly in rheumatoid factor negative RA, has been established in several case reports, ${ }^{1-5}$ but clinical trials have produced conflicting results. ${ }^{6-10}$ In a preceding clinical trial we noted that nine of 78 patients improved remarkably during a four week period of artificial feeding and had a subsequent relapse upon reinstitution of their usual diet. ${ }^{11}$ It was our opinion that in these cases food intolerance should be considered. Consequently, we asked these patients to participate in a second study, using placebo controlled, double blind rechallenges.

\section{Patients and methods}

PATIENTS

Selection of patients was described in our previous report. ${ }^{11}$

\section{STUDY DESIGN}

Total IgE serum concentration and percentage of binding for specific food antibodies of IgE, IgGl, and IgG4 classes were determined before study entrance (van de Laar $e t$ al, unpublished data). Patients were also skin tested with food, contact, and inhalation allergens. Supervised by a specially trained dietician, the patients completed a four week food diary.

At study entrance patients were reintroduced to the artificial feeding. This diet was maintained until improvement was induced. Disease activity parameters were scored every two weeks, always by the same observer. ${ }^{11}$ After induction of clinical remission patients continued to follow their allergen free diets. Three times weekly the patients were given double blind challenge food ${ }^{12} 13$ containing either previously incriminated foods or a placebo. Disease activity was scored after each challenge. When a clinically relevant increase in disease activity occurred the next challenge was delayed until disease activity had returned to normal.

\section{DIETARY MANIPULATIONS}

The allergen free diet was based on the allergen free artificial, low molecular, elementary feeding used in the previous trial (Pepti 2000; Nutricia, Zoetermeer, The Netherlands). ${ }^{11}$ Challenges were performed with an allergen free carrier, based on elementary nutrition, capable of masking normal amounts of fresh foods when taken cold from a closed cup by means of a straw.

\section{INCRIMINATION OF FOODS}

Any food that caused a positive skin reaction was considered to be suspect. Foods giving a positive $(\geqslant 2 \mathrm{U} / \mathrm{l})$ or doubtful $(0 \cdot 2-2 \mathrm{U} / \mathrm{l})$ serum specific IgE were considered suspect. In addition, any food was taken to be suspect if IgG1 or IgG4 binding exceeded the 75th centile of the 78 original patients who had completed the preceding clinical trial. ${ }^{11}$ Finally, all foods that were consumed on days before a worsening of any subjective disease parameter in the food diary, and that had not been used during periods of stability or improvement, were considered suspect.

\section{HISTOLOGICAL STUDIES}

Patients were asked to undergo biopsies of the synovial membrane and proximal small intestine. These were carried out before the installation of the allergen free diet, when the disease was active, and after six weeks during the diet if disease activity was reduced. To avoid sampling errors 10 biopsy specimens were obtained from the synovial membrane of a large joint by arthroscopy (Storz arthroscope) or arthotomy. Five biopsy specimens were taken from standard sites of the proximal small intestine by fibreoptic endoscope. The second series of synovial membrane biopsy specimens was obtained from the same areas and by the same technique. 
Tissue biopsy specimens were fixed for four hours in a sublimate-formalin mixture. The samples were then embedded in paraffin,

Table 1 Allergological and clinical findings

\begin{tabular}{|c|c|c|c|c|c|c|c|}
\hline \multirow{2}{*}{\multicolumn{2}{|c|}{ Patient No }} & \multirow[t]{2}{*}{ Skin } & \multicolumn{3}{|c|}{$R A$ skin test $\$} & \multirow[t]{2}{*}{ Diary } & \multirow{2}{*}{$\begin{array}{l}\text { Clinical } \\
\text { reaction }\end{array}$} \\
\hline & & & $I g E$ & $\operatorname{Ig} G 1$ & $\operatorname{Ig} G 4$ & & \\
\hline 1 & $\begin{array}{l}\text { Potato } \\
\text { Apple } \\
\text { Banana } \\
\text { Orange } \\
\text { Egg } \\
\text { Fish } \\
\text { Milk } \\
\text { Legumes } \\
\text { Wheat } \\
\text { Pork } \\
\text { Sesame oilł }\end{array}$ & $\begin{array}{l}- \\
- \\
+* \\
+* \\
- \\
- \\
= \\
- \\
- \\
+* \\
+\dagger\end{array}$ & $\begin{array}{l}- \\
- \\
- \\
- \\
= \\
= \\
- \\
- \\
-\end{array}$ & $\begin{array}{l}+ \\
- \\
+ \\
+ \\
+ \\
- \\
+ \\
+ \\
+\end{array}$ & $\begin{array}{l}- \\
- \\
- \\
- \\
- \\
- \\
- \\
- \\
-\end{array}$ & $\begin{array}{l}- \\
- \\
- \\
- \\
- \\
- \\
\overline{+} \\
+ \\
\overline{+} \\
+\end{array}$ & $\begin{array}{l}- \\
+ \\
+ \\
+ \\
- \\
- \\
-\end{array}$ \\
\hline 2 & $\begin{array}{l}\text { Potato } \\
\text { Apple } \\
\text { Banana } \\
\text { Orange } \\
\text { Egg } \\
\text { Fish } \\
\text { Milk } \\
\text { Legumes } \\
\text { Wheat } \\
\text { Pork } \\
\text { Coriander } \\
\text { Cardamon } \ddagger\end{array}$ & $\begin{array}{l}- \\
= \\
= \\
= \\
= \\
= \\
= \\
- \\
++ \\
++\end{array}$ & $\begin{array}{l}+ \\
- \\
- \\
- \\
- \\
+1- \\
+1- \\
- \\
-\end{array}$ & $\begin{array}{l}- \\
- \\
\overline{-} \\
- \\
- \\
- \\
- \\
- \\
-\end{array}$ & $\begin{array}{l}- \\
- \\
\overline{-} \\
- \\
- \\
- \\
- \\
-\end{array}$ & $\begin{array}{l}- \\
- \\
+ \\
+ \\
- \\
- \\
- \\
+ \\
- \\
- \\
+ \\
+\end{array}$ & $\begin{array}{l}+ \\
+ \\
+ \\
- \\
- \\
+ \\
+\end{array}$ \\
\hline 3 & $\begin{array}{l}\text { Potato } \\
\text { Apple } \\
\text { Banana } \\
\text { Orange } \\
\text { Egg } \\
\text { Fish } \\
\text { Milk } \\
\text { Legumes } \\
\text { Wheat } \\
\text { Pork }\end{array}$ & $\begin{array}{l}- \\
- \\
- \\
- \\
- \\
- \\
- \\
-\end{array}$ & $\begin{array}{l}- \\
+ \\
+ \\
+ \\
+ \\
+ \\
+ \\
- \\
-\end{array}$ & $\begin{array}{l}+ \\
+ \\
+ \\
+ \\
+ \\
+ \\
+ \\
+ \\
+ \\
+\end{array}$ & $\begin{array}{l}+ \\
+ \\
+ \\
+ \\
+ \\
+ \\
+ \\
+ \\
+ \\
+\end{array}$ & $\begin{array}{l}- \\
- \\
- \\
- \\
- \\
- \\
- \\
-\end{array}$ & $\begin{array}{l}- \\
- \\
- \\
- \\
- \\
-\end{array}$ \\
\hline 4 & $\begin{array}{l}\text { Potato } \\
\text { Apple } \\
\text { Banana } \\
\text { Orange } \\
\text { Egg } \\
\text { Fish } \\
\text { Milk } \\
\text { Legumes } \\
\text { Wheat } \\
\text { Pork }\end{array}$ & $\begin{array}{l}- \\
- \\
- \\
- \\
- \\
- \\
- \\
-\end{array}$ & $\begin{array}{l}+1- \\
- \\
- \\
- \\
- \\
- \\
- \\
+1- \\
+1- \\
-\end{array}$ & $\begin{array}{l}- \\
- \\
- \\
- \\
- \\
- \\
- \\
- \\
-\end{array}$ & $\begin{array}{l}- \\
- \\
- \\
- \\
- \\
- \\
- \\
+ \\
-\end{array}$ & $\begin{array}{l}- \\
\overline{-} \\
\overline{-} \\
\overline{-} \\
\overline{-} \\
\overline{-} \\
\overline{-}\end{array}$ & + \\
\hline
\end{tabular}

according to standard procedures, and cut into $4 \mu \mathrm{m}$ thick sections. Slides were stained with haematoxylin-eosin and with toluidine blue and Giemsa stain. An indirect immunoperoxidase technique with several monoclonal antibodies was used to determine variations in lymphocyte subsets and immunoglobulin subclass bearing cells.

ETHICS

The approval of the medical ethical committee of the medical faculty of the University of Amsterdam was obtained. The patients gave informed consent.

\section{STATISTICS}

The change of point test was applied to the hypothesis that during a number of events there should be no change in response in individual patients. ${ }^{14}$

\section{Results}

Nine patients with rheumatoid factor positive RA, for whom it was suspected that food intolerance was influencing their disease symptoms, ${ }^{11}$ were asked to participate in this study. Three patients refused further investigations: for one the study design was too demanding, in one a malignancy had developed in the meantime, and the third had had a remission of the disease. Six patients agreed to the protocol. Allergological investigations were carried out according to the protocol. Four patients had partial or total remission during allergen free feeding. In all patients most disease activity parameters changed significantly between double blinded placebo treatment and rechallenges. Thus in all four patients intolerance for some foods could be shown (table 1).

In three of six patients biopsy specimens of the synovial membrane and proximal small

Table 2 Histological findings

\begin{tabular}{|c|c|c|c|c|c|c|}
\hline \multirow[b]{2}{*}{$\begin{array}{l}\text { Patient No } \\
\text { Sex } \\
\text { Age } \\
\text { Serum IgE (IU/ml) }\end{array}$} & \multicolumn{3}{|c|}{ Normal diet } & \multicolumn{3}{|c|}{ Allergen free diet } \\
\hline & $\begin{array}{l}1 \\
F \\
65 \\
17\end{array}$ & $\begin{array}{l}2 \\
M \\
52 \\
316\end{array}$ & $\begin{array}{l}3 \\
F_{79} \\
313\end{array}$ & 1 & 2 & 3 \\
\hline \multicolumn{7}{|l|}{$\begin{array}{l}\text { Synovium* } \\
\text { Macroscopy }\end{array}$} \\
\hline $\begin{array}{l}\text { Villi } \\
\text { Hypertrophy } \\
\text { Hyperaemia }\end{array}$ & $\begin{array}{l}++ \\
++ \\
++\end{array}$ & $\begin{array}{l}+ \\
+ \\
+\end{array}$ & $\begin{array}{l}+++ \\
+++ \\
+++\end{array}$ & $\begin{array}{l}- \\
+ \\
-\end{array}$ & $\begin{array}{l}- \\
-\end{array}$ & $\begin{array}{l}+++ \\
+++ \\
+++\end{array}$ \\
\hline \multicolumn{7}{|l|}{ Microscopy } \\
\hline $\begin{array}{l}\text { Synovial lining } \\
\text { Nodular infiltrates } \\
\text { Diffuse infiltrates }\end{array}$ & $\begin{array}{l}5-6 \\
+\end{array}$ & $\frac{5}{+}$ & $\begin{array}{l}5-10 \\
+ \\
+\end{array}$ & $\begin{array}{l}2-3 \\
-\end{array}$ & $\begin{array}{l}2-3 \\
-\end{array}$ & $\begin{array}{l}5-10 \\
+\end{array}$ \\
\hline $\begin{array}{l}\text { Diffuse infiltrates } \\
\text { Plasma cells }\end{array}$ & & + & & + & & \\
\hline $\begin{array}{l}\text { IgG } \\
\text { IgM } \\
\operatorname{IgE}\end{array}$ & $\begin{array}{l}++ \\
+\end{array}$ & $\begin{array}{l}++ \\
+\end{array}$ & $\begin{array}{l}++ \\
+ \\
+\end{array}$ & $\begin{array}{l}++ \\
+\end{array}$ & $\begin{array}{l}++ \\
+ \\
+\end{array}$ & $\begin{array}{l}++ \\
+\end{array}$ \\
\hline Mast cells & ++ & ++ & ++ & ++ & - & - \\
\hline $\begin{array}{l}\text { Intestinet: } \\
\text { Villus/crypt ratio } \\
\text { Epithelial lymphocytes } \\
\text { Subepithelial lymphocytes } \\
\text { Mast cells }\end{array}$ & $\begin{array}{l}n \\
n \\
n /+ \\
+\end{array}$ & $\begin{array}{l}\mathbf{n} \\
\mathbf{n} \\
\mathbf{n} \\
++\end{array}$ & $\begin{array}{l}\mathrm{n} \\
\mathrm{n} \\
\mathrm{n} /+ \\
++\end{array}$ & $\begin{array}{l}\mathbf{n} \\
\mathbf{n} \\
\mathbf{n} /+ \\
+\end{array}$ & $\begin{array}{l}\mathrm{n} \\
\mathrm{n} \\
\mathrm{n} \\
-\end{array}$ & $\begin{array}{l}\mathrm{n} \\
\mathrm{n} \\
\mathrm{n} /+ \\
-\end{array}$ \\
\hline
\end{tabular}

*Synovial membrane: scoring: $-=$ absent; $+=$ present; $++=$ easy to look for; $+++=$ abundantly present.

Synovial lining: layers of cells.

Plasma cells positive for IgG, IgM, IgE.

Mast cells $++=5-10 /$ field $(250 \times) ;+=2-5 /$ field; $-=<2 /$ field.

†Proximal small intestine: Villus/crypt ratio: $n=$ normal $1 \cdot 5-2$; epithelial lymphocytes $n=$ normal $10-16 \%$; subepithelial lymphocytes

$n=$ normal $\pm 20 \%$ mast cells $++=5-10 /$ field $(250 \times) ;+=2-5 /$ field, $-=<2 /$ field. 
intestine were obtained before and after induction of (partial) remission by allergen elimination. The histological and immunohistological aspect of the synovial membrane and the proximal small intestine remained grossly unchanged in the three patients. In two patients, however, a marked reduction of mast cells was noted in synovial membrane and proximal small intestine during allergen elimination. Moreover, in one of these patients IgE bearing cells reduced during the dietary manipulation. Both these patients had raised serum IgE concentrations and specific IgE antibodies to foods (table 2).

\section{Discussion}

In a preceding study we failed to show any significant role for two commonly incriminated food components, lactoproteins and yellow dyes, on disease activity of RA. ${ }^{11}$ In accordance with the observation by Panush et al, ${ }^{6}$ however, it was noted that a subgroup of patients benefited from food allergen reduction.

We decided to determine the suspected food intolerance in this subgroup by double blind, placebo controlled rechallenges using foodstuffs that had been incriminated by allergological tests. Three of the nine patients were unable to participate in this additional study. The remaining six patients restarted an allergen elimination diet based on artificial food. Clinical remission was again produced in four. These patients continued the diet to test the effect of supplementary administration of food components. These consisted of either an allergen free carrier or the same carrier containing a normal amount of the suspected fresh foods. ${ }^{13}$ Evaluation of each patient took about four months. Challenging the patients with a complete panel of foods would have required more commitment than could reasonably be expected. In all four patients there was a significant difference in changes of disease activity due to placebos and allergen challenges, assessed by a change of point test. ${ }^{14}$ Only in patients 1,2 , and 4 was there a clear distinction between those foods that were tolerated and those that were not. Only patients 1 and 2 have gained long term benefit from continuing a restricted diet.

Histological aspects of the synovial membrane and proximal small intestine in food intolerant RA have not been previously studied, as far as we know. The hypothetical association between RA and allergy is supported by the finding of synovial mastocytosis and eosinophilia in a number of patients with RA. ${ }^{15-19}$ It is as yet unclear whether this finding is related to the pathogenesis or to the complications of drug treatment. ${ }^{20}$ It was possible, however, to show a relation between the activity of synovitis and mast cell infiltration. ${ }^{19-21}$ The role of the mast cell in synovitis and cartilage destruction was established by van den Broek et al. ${ }^{22}$ We were able to study the histological changes during food allergen elimination in three food intolerant patients with RA. Although clinical reduction of inflammatory joint parameters was obtained by administration of the allergen free diet, reduction of inflammation as expressed histologically was only moderate. In patients 2 and 3 it was noted, however, that although mast cells were scattered throughout the subsynovial layers in the first biopsy specimens, they were not found during elimination of food allergens (table 2). The disappearance of IgE bearing cells in patient 3 during food antigen exclusion is also remarkable (table 2). This finding agrees with the histological findings in food intolerant children by Rosekrans et al. ${ }^{23}$ Moreover, a considerable reduction in mast cells scattered throughout the lamina propria and submucosa of the proximal small intestine was seen in patients 2 and 3 during allergen free diets. Again in patient $3 \mathrm{IgE}$ bearing cells seemed to disappear from the proximal small intestine during antigen elimination (table 2). It is interesting that patient 1 had a normal IgE serum concentration, whereas the second and third patients had increased IgE serum concentrations. In addition, patients 2 and 3 had specific IgE antibodies to several foods.

In conclusion, our data emphasise the existence of food intolerance in a minority of patients with rheumatoid factor positive RA. The diagnosis still depends on clinical judgment, however, as no single test is adequate. The presence of specific food antibodies and skin reactions, as well as the histological changes, suggests that an allergological/immunological mechanism is responsible for the demonstrated intolerances. Food intolerance in rheumatoid factor positive RA may be fairly uncommon, however; a prevalence of $5 \%$, as suggested by Panush for rheumatoid factor negative RA, may also be correct for the rheumatoid factor positive disease. ${ }^{5}$ Moreover, demonstration of food intolerance in RA is laborious and long term therapeutic effects are rare. Dietary manipulation in the treatment of RA must still be considered experimental.

We thank Dr P Snel for performing the endoscopies of the intestine Miss J Nieuwenhuis, measurement technician, and Mrs J Hulsing, dietician, for their assistance, Professor R C Aalberse and Dr D P Bruynzeel for critically reviewing the manuscript, and Nutricia for their cooperation. This study was financially supported by a grant from 'het Praeventiefonds'.

1 Parke A L, Hughes G R V. Rheumatoid arthritis and food: a case study. BMF 1981; 282: 2027-9.

2 Wiliams $R$. Rheumatoid arthritis and food: a case study. $B M F$ 1981; 283: 563 .

3 Panush R S, Stroud R M, Webster E M. Food induced (allergic) arthritis. Arthritis Rheum 1986; 29: 220-6.

4 Lunardi C, Bambara L M, Biasi D, et al. Food allergy and rheumatoid arthritis. Clin Exp Rheumatol 1988; 6: 423-6.

5 Panush R S. Food induced ('allergic') arthritis: clinical and serologic studies. F Rheumatol 1990; 17: 291-4.

6 Panush R S, Carter R L, Katz P, Kowsari B, Longley S, Finnie S. Diet therapy for rheumatoid arthritis. Arthritis Rheum 1983; 26: 462-71.

7 Darlington L G. Does food intolerance have any role in the aetiology and management of rheumatoid disease. $A n n$ Rheum Dis 1985; 44: 801-4.

8 Darlington L G, Ramsey N W, Mansfield J R. Placebo controlled, blind study of dietary manipulation therapy in rheumatoid arthritis. Lancet 1986; i: 236-8.

9 Felder M, De Blecourt A C E, Wüthrich B. Food allergy in patients with rheumatoid arthritis. Clin Rheumatol 1987; 6: $181-4$.

10 Beri D, Malaviya A N, Shandilya R, Singh R R. Effects of dietary restrictions on disease activity in rheumatoid arthritis. Ann Rheum Dis 1988; 47: 69-72.

11 van de Laar M A F J, van der Korst J K. Food intolerance in rheumatoid arthritis. I. A double blind, controlled trial of the clinical effects of elimination of milk allergens and of the clinical effects of elimination of milk aller
azo dyes. Ann Rheum Dis 1992; 51: 298-302. 12 Sampson H A, Buckley R H, Metcalfe D D. Food allergy.
JAMA 1987; 258: 2886-90. 
13 Carter C M, Egger J, Soothill J F. A dietary management of severe childhood migraine. Human Nutrition: Applied Nutrition 1985; 39: 294-303.

14 Seagle S, Castellan N J. Nonparametric statistics for the behaviour sciences. 2nd ed. New York: McGraw-Hill, 1988.

15 Dawes P T, Smith D H, Scott D L. Massive eosinophilia in rheumatoid arthritis. Clin Rheumatol 1986; 5: 62-5.

16 Panush R S, Franco A E, Schur P H. Rheumatoid arthritis associated with eosinophilia. Ann Intern Med 1971; 75: 199-205.

17 Schumacher H R. Ultrastructure of the synovial membrane. Ann Clin Lab Sci 1975; 5: 489-98.

18 Helder A W, Feltkamp-Vroom T M, Nienhuis R L F. Electron and light microscopical observations and sero-
logical findings in rheumatoid arthritis. Ann Rheum Dis logical findings in
$1973 ; 32: 515-23$.

19 Crisp A J, Chapman C M, Kirkham S E, Schiller A L, Krane
S M. Articular mastocytosis in rheumatoid arthritis. Arthritis Rheum 1984; 27: 845-51.

20 Malone D G, Wilder R L, Saavedra-Delgado A M, Metcalfe D D. Mast cell numbers in rheumatoid synovial tissue. Arthritis Rheum 1987; 30: 130-7.

21 Godfrey H P, Ilardi C, Engber W, Graziano F M. Quantitation of human synovial mast cells in rheumatoid arthritis and other rheumatic diseases. Arthritis Rheum 1984; 27: $852-6$.

22 van den Broek M F, van den Berg W B, van de Putte L B. The role of mast cells in antigen induced arthritis in mice. f R heumatol 1988; 45: 544-51.

23 Rosekrans P C M, Meijer C J L M, Cornelisse C J, vd Wal $A M$, Lindeman J. Use of morphometry and immunohistochemistry of small-intestinal biopsy specimens in the chemistry of small-intestinal biopsy specimens in the
diagnosis of food allergy. $\mathcal{J}$ Clin Pathol 1980; 33: 125-30. 